\title{
THE EXPOSURE OF ACEH HEROINE NARRATIVE: A POTENTIAL TOOL TO PROMOTE GENDER EQUALITY
}

\author{
Muhammad Iqhrammullah \\ Faculty of Mathematics and Natural Sciences, University of Syiah Kuala \\ m.iqhram@oia.unsyiah.ac.id
}

\begin{abstract}
Despite many ratifications of international agreement on gender equality by Indonesia, the women still face many kinds of gender-based discrimination. In Aceh's communities there found a resistance to gender equality due to the contradicting value with religion and culture. Education, in the other hand, could play an important role to reduce gender inequality, but should be incorporated with the changing in religion and culture. Aceh in history, was never out of stock producing women leaders (heroine), most prominently Ratu Safiatudin, Laksamana Malahayati, and Cut Nyak Dien. Aceh heroine narrative was found to be a potential tool to tackle inequality among men and women. This study suggests three major findings regarding the exposure: 1) There was a lacking of integrated gender equality education in the narratives, 2) The cognitive dissonance occurrence and 3) The exposure motivated boys to be more competitive against girls. Overall, the exposure of Aceh heroine narratives gave positive effect for boys to increase their competitiveness and acknowledge women's capabilities, meanwhile for girls they became inspired in pursuing their dreams and even to lead.
\end{abstract}

Keyword: Aceh, gender equality, education, senior high school, narrative.

\section{INTRODUCTION}

The struggle on achieving equality between men and women as it was initially set up in the Universal Declaration of Human Rights in 1948 has long lasted. A series of international agreements has been conducted to institute women's rights, most prominently the Convention on the Elimination of all forms of Discrimination Against Women (CEDAW) in 1979, the UN Security Council Resolution 1325 in 2000 on women, peace and security, Beijing Platform of Action and Millenium Development Goal 3, 'To promote gender equality and empower women,' that newly reinterpreted with more specific details in Sustainable Development Goal 5, 'Achieve gender equality and empower all women and girls', launched in 2015. Indonesia has ratified CEDAW in 1981 and UN Convention on Political Rights of
Women in 1958 (Robinson and Bessell, 2002).

However, the ratification of those international agreements does not instantly close the gap between men and women. In fact, unequal access of opportunities, discriminative attitude and violence against women are still widely to be found. Indonesia's National Commission on Violenee against Women (Komnas Perempuan) reported there were 348.446 violence against women cases within 2017. The latest Human Development Index (HDI) report in 2015, by United Nations Development Program (UNDP), shows 0.052 points gap between Indonesian men's HDI $(0,712)$ and women's HDI $(0,660)$ putting the country in $113^{\text {th }}$ position out of 188 countries. Women participation in economic structure and decision-making position is 
highly encouraged to close the gap. Besides the institution of women protection policies, changing perception on women in cultural structure can also be effective to achieve gender equality.

In the most northwest part of Indonesia, Aceh province, the term of 'gender equality' is considered 'taboo' and does not receive a warm welcome by the communities. Different from the attitude exhibited by Balinese community, although they were not familiar with the term of gender equality but they considered it as mandatory (Wiasti, 2012). Gender equality is mostly perceived as a negative connotation of western value that contradicts local belief and culture. The interview with Irma Sari, a head director of Aceh Women for Peace Foundation (AWPF), also resonated the same thing. While they were gathering in meunasah (a small mosque), they were distracted by stones thrown at them, but no injuries. There was a rejection from the community against the women empowering effort carried out by AWPF, thought it was such a group of deviant sect teaching. This situation hinders gender equality progress, moreover with the implementation of Sharia law regulating gender related issues, opens more space for discriminative policies against women.

Within a hard situation like this, women in Aceh are facing many genderbased abuses. Aceh's government has been trying to safe-guard women with qanun (sharia laws) that does not allow women to wear 'too revealing clothes' and stay out past curfew (Danial, 2012). But the pretext of 'giving protection to women' without looking the root cause of high rate sexual abuse against women could falsely address the real problem (Herlanita, 2015). For example, due to the lacking of awareness of gender equality, the abuse was simply justified and women mostly did not know they have right to pursue justice due to their submissive position in patriarchal cultural structure. A head director of Aceh Women for Peace Foundation, Irma Sari, said that "It was okay for husbands to physically abuse their wives and the wives didn't know it was something wrong”.

In the old belief of MDG, girls in school is equal to women empowerment, so when the access of pursuing education for girls is granted, the equality can be achieved. In facts, many women are still suffering the discriminative attitude and deep-rooted culture of patriarchy (Susanto, 2015). While achieving substantive gender equality is important, one to be considered is bringing gender equality in the education itself. Vaughan (2016), however, argued education alone is not enough to achieve gender equality. Together with two other essential aspects, religion and culture, education could be a strong instrument to introduce and set a basic understanding of gender equality.

From the moment happened hundred years ago in Aceh, it was hard to imagine how crumble the justice for women is, even when Islam was at the strongest influence then. During the monarchy period of time, Aceh experienced women leadership under these names: Sultanah Nihrasiyah (1400-1428), Ratu Safiatuddin (1641-1675), Sultanah Naqi al-Din Nur alAlam (1675-1678), Sultanah Zaqi al-Din Inayat Syah (1678-1688), and Sultanah Kumalat Syah Zinat al-Din (1688-1699) (Raditya, 2017). Not only in leadership, 
women in Aceh historical narratives also exhibited their capability to handle security issues. There were two womenonly army corps namely Suke Kawai Istana and Si Pai Inong. Each of the two was given one specific task, Suke Kawai Istana was in charge to keep the palace safe meanwhile Si Pai Inong was in charge directly in war events. From Aceh's aristocratic family there was born the first women admiral in modern world, Laksmana Malahayati (1589-1604) was notably known for her war abilities in fighting colonials (Anonymous, 2008; Restianti, 2009).

Aceh in historical moment had never out of stock for female leaders, namely Pocut Baren, Pocut Meurah Intan, Cutpo Fatimah and Cut Nyak Dien, were leading both men and women to fight against Dutch colonialization. Besides in history books, stories of the Aceh heroines' bravery were made into movies, most prominently Cut Nyak Dien (1988) and Laksmana Malahayati (2007) (Siapno, 2006). Through above Aceh heroine narrative, we could understand that Aceh women could have equal opportunities to lead and even to get involved in the most masculine work like war. Although it is contradictory comparing to what happens now. These lead us to several questions that become the baseline of this study:

1. How is the exposure of gender equality education in Aceh's schools?

2. How intense is the exposure of Aceh heroine narratives in schools and how the teachers relate them to gender equality?
3. Does the exposure of Aceh heroine narrative affect their perspective on gender equality?

\section{RESEARCH METHODOLOGY}

This study is qualitative in nature, carried out with interview and literature studies. The interview was conducted by asking prepared questions and welcome further explanation from the interviewees. The questions were designed to holistically explore the cultural structure in schools that is related to gender inequality occurance. Knowing the real situation in school is important because it could affect their way to perceive gender equality. The following questions were asked to understand the exposure of gender equality education, and the exposure of Aceh's heroine narrative and its effect to their perspective. This research employed thematic approach for the interview data analysis. 25 students were interviewed for this study, they were from 8 pesantren(s) (an Islamic boarding school), 10 Muslim majority regular schools, and 1 Christian majority school. These schools were located across 10 out of 23 regencies and cities in Aceh. And 1 additional interview with a gender activist (Irma Sari from AWPF) was conducted to give deeper understanding about the gender equality in Aceh. The span of interview for this study was two weeks, started from June $11^{\text {th }}$ up until 25 ${ }^{\text {th }}, 2017$.

\section{RESULTS AND DISCUSSION \\ Gender Inequality Experience in Schools}

The finding suggests at least there were three kinds of discrimination happened in school that girls face. Firstly, 
Girls were not allowed to be in the top leadership position, such as being a head of prefectorial board. They were less likely trusted to fill the position because of negative stereotype attached to them. Girls were considered both mentally and physically weak which was the negative stereotypes attached to them and perceived as girls' nature. There was a popular notion among the students that women should not lead men and only allowed to lead the other women and their children.

Students from pesantren said girls were given an opportunity to lead among girls because their schools are sexsegregated. So, they had two prefectorial boards in one school, each for boys and girls. The female students also expressed their satisfaction over the opportunity, although in the other hand the head of boy's prefectorial board had more privilege such as organizing major school's events and easily communicating with the headmaster.

Additionally, one student said there was a female head of prefectorial board in her junior high school. However, in junior high school the prefectorial board has less authority and does not have a lot of responsibilities as much as in senior high school. Therefore, leading a prefectorial board in junior high school is considered less challenging that a girl is allowed to carry out the leadership tasks. One boarding school in Lhokseumawe regency allows girls to lead the prefectorial board and had a girl elected as the head. However, in the recent few years, the school did not have any girl to run the leadership position.

The notion 'Girls as misfortune carriers for a nation if they lead' was also believed by many students. The notion to believed, derived from Islamic teaching, lead the major reason to not allowing girls be in the top position of students' organization. Not only in the student's internal organization like prefectorial board, the negative comment on women leadership also went out to the school organization structure. Students believed the headmaster should not be a woman. It clearly shows, the ceiling glass against women to reach the top position does not only stay in the internal students' organization, but rather to be carried out to judge the surroundings. Ceiling glass which is the 'transparent' barrier for women to step into top position, is not uncommon in Indonesia (Subono, 2012).

Secondly, girls were less likely gain equal access to explore their talents through extracurricular activities. This kind of discrimination most likely only happened in boarding school either pesantren or regular one. For example, they were not allowed to participate in a competition where boys and girls were mixed in a group, especially when there was a possibility for them to make skin contact with the opposite sex. There was also a statement that "girls are not allowed to carry out the task during Indonesian flag ceremony in their school”. One pesantren student experienced the discrimination where she and the other girls in the group were canceled to participate in a provincial scout's event and giving more priority over the boys.

There was a norm developed in school that girls should only do feminine works while boys should only do masculine works. Both boys and girls could receive negative stigma if they break 
the norm. For the most part of the students believed in this norm. This can be a barrier, not only for girls but also for boys, to explore their talent. This finding could suggest that the stereotypical gender-role in almost all Aceh's schools is divided by the term of masculinity and femininity accord.

Thirdly, girls received extra judgement from the teachers and students. The suggestion that developing countries are facing a different kind of gender inequality could be wrong (Cowell and O’Flynn, 2016). It is true that girls are still having a difficult access for education but for girl students they also received unfair judgement from the teachers. It was often found for teachers to judge the boys could do many bad things while the girls should not do anything wrong. It is more reasonable for boys to skipping class compare to girls. Girls have to be in a perfect behavior according to their standard.

\section{Gender Equality Education in Schools}

Sardjujani (2013) suggests that Indonesia is still lacking for gender mainstreaming in schools and has limited technical capacity. The use of images and texts in Indonesian school textbooks is massively full with gender bias, particularly from Year 1 until Year 12, although in Year 6 simple messages on gender-based violence start to be incorporated (Utomo, et al., 2008). Therefore, it is not surprising to find gender equality was not commonly discussed in Aceh's schools. None of the students ever heard a discussion of gender equality in the class, but gender bias was commonly deliver in rhetoric speeches by either male or female teachers, saying:
"Our gender equality is not westernized gender equality, women should respect men regardless their bad behavior because they are the leaders.”

But the idea of gender equality found its way through debating club, either in pesantren or regular school. Gender equality was mostly found in various competitive debate topics, it intrigued students to deepen their knowledge on gender equality. Iqhrammullah and Zuelda (2017) suggested competitive debate could raise students' critical thinking and social awareness. Irma Sari also suggested to improve Aceh women's critical thinking to make them more aware on gender equality issues.

NGOs also helped to get gender equality inside the schools. Students claimed there were some gender equality trainings in their schools. Although the discussion was not deep and only lasted for several hours in one day. APWF had also held a training for senior high school students, though it focused more on reproductive health. Irma Sari said it was hard for her organization to get permission from the schools and the local government agencies to conduct such event.

\section{Aceh Heroine Narrative in Schools}

Students believed they were exposed with the Aceh heroine narratives through textbooks (in history and even English subjects), internet, theatrical play, information board, movies, and oral information from teachers, schoolmates, and relatives. The similarity was found between the pesantren students and regular school students. For the most part, 
they found the narrative in the school textbooks alongside with the Aceh's history and in paragraphs from English textbook. The other sources of information were varied according to the individuals, some found the narratives through internet where articles about Aceh heroine is massively posted in either official or nonofficial websites. Students in drama clubs were exposed with the narratives, mostly Cut Nyak Dien's. There was also a film screening of Cut Nyak Dien's movie in the class.

Discussion of Aceh heroine narrative was less intense in the class, unless it is a history class. It is not common among the schoolmates to discuss about the narratives, only in one or two special occasions, for example after having a trip from the museum. However, the narrative also being told by the students' relatives such as their grandparents. But the students claimed through the exposure, there were none of which the narratives were related to gender equality.

\section{Feeling Inspired}

Most of the students, both boys and girls, found themselves inspired by the Aceh heroine narratives. Boys believed women should not be undermined for their capabilities which was different from their previous statement stating girls are weak. For girls, they were motivated to pursue their dreams, to lead, and to be acknowledged for their talent. Although for some girls, the idea of leadership did not really fit their belief.

The commonly distinguished values that the current widely distributed narratives shows are religion, bravery and patriotism. The depiction of Cut Nyak
Dien herself was mostly as a religious person who was carrying up jihad fisabilillah (in the cause of Allah) label in her war campaign. Thus, not surprising if the narrative could inspire the students in religious aspect or in patriotism.

There is a sense of competition when the boys responded the question, "we [boys] have to be better than them [the heroine figures]". However, they had stronger impression on how men are forever undefeated by women. They thought women are born to be submissive to men as how God has created them to be. This finding suggests boys and girls could had experienced cognitive dissonance, where the facts contradicted their current belief.

\section{Meanwhile in A Non-Muslim Majority School}

One student was interviewed for this study told a very different shape of situation regarding gender inequality experience in his school. They had a girl to be the head of prefectorial board and become proud of the achievement. Nevertheless, stereotypical gender-role persisted in the school where men will get cynical impression for doing girls' jobs, but not vice versa. The students were not well-exposed with gender equality education, only a seminar held by local government agencies that had a basic material on gender issues. The exposure of Aceh heroine narratives was lacking, the interviewee even only knew one, Cut Nyak Dien, but not familiar to the others. The religious heroine character, Mother Teresa, was discussed out of religion textbook. The teacher suggested a stereotype that girls have to be calm and soft-hearted like Mother Teresa. The 
interviewee then personally thought the difference of culture and religion could be the reason why they are different than Muslim majority schools in term of gender equality.

\section{Further Analysis}

Basically, the similar patterns found regarding the gender equality education either in pesantren or regular schools, they are lacking. Sex-segregated schools provide more access of opportunity for girls to climb up into top position in prefectorial boards, even though the gender parity is still questionable. We can assume they have similar background pertaining gender equality where patriarchal culture is strongly influencing and gender inequality is manifested. They also shared the similarity on how they were well exposed to Aceh heroine narratives, but found hard to relate the narrative with gender equality. There are differences in perspective between girls and boys affected by the Aceh heroine narrative; some girls believe women can be leaders while some other girls along with the boys believe women cannot be leaders. Amidst the contradiction of the widely exposed narrative which suggests equality for men and women in leadership and persisted gender inequality, these three points from our study is worth to consider:

1. Less integration of gender equality education

Nurlimah (2015) in her study on how gender related articles in a newspaper could change the readers' perspective, suggested frequency and intensity of gender equality content contribute the most in changing readers' perception. Meanwhile the schools in Aceh exposed the heroine narrative in irregular frequency. Thus, does not help the students to constantly hearing the narrative, though they are familiar with it.

The provided heroine narratives' content unfortunately did not include explicit gender equality messages. The teachers are lesslikely to explain the content in gender equality aspect. Thus, there is no such intense content of gender equality in the narratives. To be able to effectively change students' perception an explicit message of gender equality has to be integrated in the narratives. Some researches suggested the persuasive narrative could change individuals' not only perception but also behavior (Wang and Calder, 2006; Escalas, 2007; Kusumastutie and Faturochman, 2004), although Hormes, Rozin, Green, and Fincher (2013) suggested it can only last for short-term.

\section{Cognitive Dissonance}

When someone is confronted with new fact or information that contradicts their current belief, they will feel discomfort. The two or more incompatible cognitions could lead unpleasant psychological tension, called as cognitive dissonance. This state of dissonance brings a lot of discomfort that pushes us to reduce it by changing our attitude (Hockenbury, Nolan, and Hockenbury, 2015). The way people reduce the dissonance state could lead into various changes of 
attitude to accept or even to decline the fact.

It is hard to analyze how exactly the students changed their attitude after being exposed with Aceh heroine narrative because: firstly, it was not their first time exposed thus the instant change of attitude cannot be measured; secondly there was possibility the students were not aware of the contradicting facts due to the absence of explicit gender equality message in the narrative, thus we do not know whether or not they underwent the dissonance state. But when they were asked how did the narrative affect their perspective on women, their perspective changed instantly from their previous statement, gave us a sign of cognitive dissonance. So rather analyzing the cognitive dissonance from the long-time exposure of Aceh heroine narrative, it is more likely we analyzed when the students were confronted with questions that contradicted their current belief.

At first, boys believed women are weak and not eligible to do masculine work. But when confronted with question how the narrative changed their perspective, they changed to believe not all women are weak and women should not be undermined for their capabilities. The students were trying to justify their previous statement that at least, it was partially correct. The other boys responded with less responsive answer by giving out more religious notion on how a woman should not lead men and can bring misfortune. It can also be considered as the students' effort to avoid contradicting information so they can reduce the dissonance. Some girls who felt the women leadership does not fit their belief was giving the similar response, "we should know our place and should not pursue the leadership position”.

The various changes of attitude due to cognitive dissonance could lead us into an unpredictable result for the gender equality education integration in the Aceh heroine narrative. This could also lead a distortion of facts, thus the message on gender equality would not be effective. However, for students who do not undergo the dissonance state, the narrative could help them strengthening their perception on gender equality.

3. Competition between boys and girls There had been many studies regarding men and women competitiveness to understand both behavior in competitive environment (Gneezy, 2009; Booth and Nolen 2009). In this study, boys expressed a sense of competition to achieve more than heroine figures had. While for girls, they did not exhibit any sense of competition, but rather focus on self-attainment. This can be understood because boys have more confident and supportive attitude to competitions (Niederle and Vesterlund, 2011). As a complement, boys also response to not undermine girls' capabilities, 
showing that they considered girls as equal rivals. The exposure of Aceh heroine narrative gave a good effect on the students' perception, for boys they felt more competitive and saw girls equally, meanwhile for girls they became more inspired to achieve their dream.

Aceh heroine narrative can be a potential tool to tackle gender inequality in schools. Not only it suggests women to be treated equally, but also it is naturally attached to Aceh culture and Islamic religion. Transferring gender equality messages through the narrative can be potentially replicated and used in another Indonesia's provinces. It does not close an opportunity for the other heroine figures in Indonesia to be carried out in gender equality education.

\section{CONCLUSION}

We can draw a conclusion out of this study through the initial three set questions:

1. How is the exposure of gender equality education in Aceh's schools?

Gender equality education in Aceh's schools was severe, besides the schools had not been gender mainstreamed to begin with. Gender equality discussion in schools was full with gender bias. Girls seemed to experience poor gender equality in prefectorial board, extracurricular activities, and learning process. It was clear, the gender inequality is manifested in Aceh's schools.

2. How intense is the exposure of Aceh heroine narratives in schools and how the teachers relate them to gender equality?

There were many sources of exposure for Aceh heroine narrative in schools but there was lacking of effort to relate the narrative to gender issues.

3. Did the exposure of Aceh heroine narrative affect their perspective on gender equality?

Yes, it affected the students variously. But the lacking of gender equality integration in the narratives made the students not able to relate them with gender issues. We should be aware of the cognitive dissonance to occur due to the two clashing facts of the students' cognition. Overall the exposure gave positive effect for boys to increase their competitiveness and acknowledge women's capabilities, meanwhile for girls they became inspired by the narrative to pursue their dreams and even to lead.

Aceh heroine narrative is a potential tool for gender equality education in Aceh's senior high schools. Nevertheless, the narrative alone cannot lift the massively manifested gender inequality. It takes the whole school to be gender mainstreamed along with the teachers and the top position officers included (Mahpur, 2012). We then encourage further study in quantitative approach and develop better methodology to understand further on the effect of the narrative's exposure. 


\section{BIBLIOGRAPHY}

Anonymous. (2008, February). Admiral Keumalahayati. Retrieved July 01, 2017, from http://melayuonline.com/eng/personage/dig/330/admiral-keumalahayati

Bessell, S., \& Robinson, K. M. (2003). Women in Indonesia: gender, equity and development. Singapore: Institute of southeast Asian Studies.

Cowell, G., \& O'Flynn, A. (2016). GENDER EQUALITY AND EMPOWERMENT OF WOMEN AND GIRLS IN THE UK: Meeting the challenge of the Sustainable Development Goals(United Kingdom, British Council). British Council.

Danial. (2012). Qanun Jinayah Aceh dan Perlindungan HAM (Kajian Yuridis-Filosofis). AlManahij,6(1)., 85-98. Retrieved June 27, 2017, from http://ejournal.iainpurwokerto.ac.id/index.php/almanahij/article/view/590

Dollar, D., \& Gatti, R. (1999). Gender Inequality, Income, and Growth: Are Good Times Good

for Women? Policy Research Report on Gender and Development, 1st ser., 1-42. Retrieved June 10, 2017, from http: //www.worldbank.org/gender/prr.

Escalas, J. E. (2006). Self-Referencing and Persuasion: Narrative Transportation versus Analytical Elaboration. J Consum Res, 33(4), 421-429. http://doi.org/10.1086/510216

Helanita, K. (2015, June 13). Aceh's curfew for women and the urgency of gender equality law. Retrieved June 26, 2017, from http://www.thejakartapost.com/news/2015/06/13/aceh-s-curfew-women-andurgency-gender-equality-law.html

Hockenbury, S. E., Nolan, S. A., \& Hockenbury, D. H. (2015). Psychology(7th ed.). New York, United State of America: Worth.

Hormes, J. M., Rozin, P., Green, M. C., \& Fincher, K. (2013). Reading a book can change your mind, but only some changes last for a year: food attitude changes in readers of The Omnivore's Dilemma. Frontiers in Psychology, 4, 778.

http://doi.org/10.3389/fpsyg.2013.00778

Iqhrammullah, M., \& Zuelda, N. (2017). Landscape of Competitive Debate in Aceh: Benefit, Achievement, and Challenges. The 1st International Conference on Language, Literature, and Teaching,47-54. ISSN: 2549-5607

Kusumastutie, N. S. \& Faturochman. (2004). Analisis Gender pada Iklan Televisi dengan Metode Semiotika. Jurnal Psikologi,(2)., 130-141. Retrieved June 26, 2017, from http://fatur.staff.ugm.ac.id/file/JURNAL\%20\%20Analisis\%20Gender\%20Iklan\%20TV.pdf

Lestari, S. (2017, March 07). KDRT tertinggi dalam kekerasan atas perempuan di Indonesia BBC Indonesia. Retrieved June 26, 2017, from http://www.bbc.com/indonesia/indonesia-39180341

Mahpur. (2012). Baseline Study Kesetaraan Gender di UIN Malang. EGALITA,1(2). Retrieved June 10, 2017, from http://ejournal.uinmalang.ac.id/index.php/egalita/article/view/1924 
Nurlimah, N. (2005). Pengaruh Informasi Kesetaraan Gender pada Rubrik Swara "Kompas” terhadap Persepsi Pembaca tentang Kesetaraan Gender. Mediator,6(2). Retrieved June 10, 2017, from http://ejournal.unisba.ac.id/index.php/mediator/article/viewFile/1195/749

Raditya, I. N. (2017, June 10). Ketika Serambi Mekkah Diperintah Para Sultanah. Retrieved June 26, 2017, from https://tirto.id/ketika-serambi-mekkah-diperintah-para-sultanah$\mathrm{cqkW}$

Restianti, H. (2009). Kaum Wanita dalam Pergerakan Kebangsaan Indonesia. Bandung: Bandung Puri Delco.

Sardjunani, N. (2013). Gender Equality in Education in Indonesia. Policy Brief(Indonesia, ACDP Indonesia). ACDP Indonesia. Retrieved June 27, 2017, from http://www.acdp-indonesia.org/en/acdp-publications/policy-brief/

Siapno, J. A. (2006). Gender, Islam, nationalism and the state of Aceh. London: RoutledgeCurzon.

Susanto, N. H. (2015). Tantangan Mewujudkan Kesetaraan Gender dalam Budaya Patriarki. MUWAZAH,7(2). Retrieved June 26, 2017, from http://e-journal.stainpekalongan.ac.id/index.php/Muwazah/article/view/517/680

Utomo, I. D., McDonald, P., Hull, T., Rosyidah, I., Hattimah, T., Idrus, N. I., . . Makruf, J. (2009). Gender depiction in Indonesian school text books: progress or deterioration. Marrakech, IUSSP International Population Conference,1-33. Retrieved June 27, 2017, from http://www.paramadina-pusad.or.id/en/umumen/gender-depiction-in-indonesian-school-textbooks-progress-or-deterioration.html

Vaughan, R. P. (2016). Gender equality. The Sustainable Development Goals Report The Sustainable Development Goals Report 2016,20-21. doi:10.18356/4043e346-en

Wang, J., \& Calder, B. J. (2006). Media Transportation and Advertising. J Consum Res , 33(2), 151-162. http://doi.org/10.1086/506296

Wiasti, Ni Made. (2012). Gender dan Kesetaraan dan Keadilan Gender: Studi Tentang Pengetahuan dan Sikap Masyarakat Bali. Jurnal Studi Jender SRIKANDI. Retrieved June 10, 2017, from https://ojs.unud.ac.id/index.php/srikandi/article/view/2894 